\title{
Clinical importance of Campylobacter pyloridis and associated serum IgG and IgA antibody responses in patients undergoing upper gastrointestinal endoscopy
}

\author{
LINDA BOOTH, G HOLDSTOCK, H MACBRIDE, P HAWTIN, JR GIBSON, \\ A IRELAND, J BAMFORTH, CLAIRE E DUBOULAY, RS LLOYD, AD PEARSON \\ From the Departments of Bacteriology, Gastroenterology, and Pathology, Southampton General Hospital, \\ Southampton
}

SUMMARY Campylobacter pyloridis was isolated from $77 \%$ of $220(35 \%)$ unselected adults undergoing gastroscopy. Isolation was significantly associated with histological gastritis $(p<0.0001)$, duodenal ulcer ( $p>0.0001)$, and to a much lesser extent, with gastric ulcer $(p<0.05)$. The relation between the isolation of $C$ pyloridis and peptic ulcer seemed to be independent of coexisting gastritis. In those with no endoscopic or histological evidence of disease there was no relation between isolation and increasing age.

Antibody responses to a whole cell sonicate of a strain of $C$ pyloridis were measured by means of an enzyme linked immunosorbent assay (ELISA). Increased IgA $(p<0.0001)$ and $\operatorname{IgG}(p<$ 0.0001 ) antibody titres were found in patients with $C$ pyloridis. Peptic ulceration or gastritis were present in $78 \%$ and $100 \%$ of patients with a high concentration of IgG and IgA, respectively, but in only $9 \%$ and $18 \%$ of those with low titres.

These results provide further evidence for a possible pathogenic role of these organisms in gastric disease and suggest that immunological markers of their presence might be useful non-invasive indicators of disease.

The reports by Warren ${ }^{1}$ and Marshall ${ }^{2}$ showing an association of unidentified curved bacilli (now named Campylobacter pyloridis ${ }^{3}$ ) adherent to gastric epithelium with chronic gastritis led to several centres investigating the relevance of this potentially important discovery. Preliminary reports have since appeared, showing that between $39 \%$ and $64 \%^{3-7}$ of patients attending for endoscopy have this organism on culture or microscopy. ${ }^{4-8}$ The presence of $C$ pyloridis is associated with an inflammatory infiltrate of the antrum ${ }^{910}$ and arguably with peptic ulcer disease. $^{49}$ Its presence may ${ }^{11}$ or may not ${ }^{4}$ correlate with gastric $\mathrm{pH}$. Furthermore, it seems to cause a systemic immune reaction. ${ }^{612-14}$

Serum antibody responses to the organism could be "disease" indicators, irrespective of whether the organism has a causative role or is simply a secondary invader. If it is a secondary invader mucosal damage from any cause could facilitate the presentation of

Accepted for publication 26 September 1985 antigen to the reticuloendothelial system. This study was designed to investigate the correlations between gastroduodenal disease, the isolation of the organism from antral biopsies, and serum IgG and $\operatorname{IgA}$ antibody responses to the organism.

\section{Patients and methods}

Unselected adult outpatients attending for diagnostic endoscopy were included in the study. Most were referred for the evaluation of abdominal pain. A history of ulcers and any relevant surgery was recorded. Two antral biopsy specimens were collected from each patient, together with additional specimens as dictated by the endoscopic findings. One biopsy specimen was submitted for routine histology, the other for bacteriology.

\section{HISTOLOGY}

Histological classification of gastritis was based on 
that of Whitehead. ${ }^{15}$ Thus a grade of 0 indicated normal, 1, superficial gastritis, 2, chronic gastritis, 3, chronic atrophic gastritis, and 4, chronic atrophic gastritis with intestinal metaplasia.

\section{BACTERIOLOGY}

The second antral biopsy specimen was placed in a sterile container and transported to the microbiology laboratory within two and a half hours of collection. It was rolled over the surface of blood, chocolate, and VPT (vancomycin, polymyxin, and trimethoprim) agar plates (Skirrow's medium), and a Gram stained smear was examined for the presence of Gram negative rods. The culture plates were incubated in an atmosphere of $10 \%$ carbon dioxide and $90 \%$ nitrogen at $37^{\circ} \mathrm{C}$ for one week and were examined at intervals of 24 hours after the initial 48 hours. Typical colonies were designated $C$ pyloridis if shown to be curved or coccobacillary Gram negative rods and if they were oxidase and catalase positive.

\section{ANTIBODY STUDIES}

Antibodies to $C$ pyloridis were measured in the sera of the first 140 patients subjected to endoscopy and also in a control group who did not undergo endoscopy. This control group included healthy children, who had participated as controls in a previous unrelated study, and blood donors. Also included were surplus sera from blood submitted to a diagnostic laboratory for serological investigations unrelated to gastroduodenal disease. This population was not considered to be ideal as a control group, as the endoscopic and histological normality of their gastrointestinal tracts was not ascertainable.

\section{ASSAY METHOD}

Serum IgG and IgA antibodies were measured by an enzyme linked immunosorbent assay (ELISA.) A whole cell sonicate of a representative strain of $C$ pyloridis was selected on the basis of preliminary serotyping, and typical protein profile in polyacrylamide gel electrophoresis, as described elsewhere, ${ }^{16}$ was used as the antigen at a concentration of $1 \mathrm{mg} / \mathrm{l}$. Doubling dilutions of serum, starting at $1 / 100$, were incubated on prepared antigen coated plates at $37^{\circ} \mathrm{C}$ for two hours. After washing rabbit antihuman IgG or IgA peroxidase conjugate was added at a dilution of $1 / 2000$ and $1 / 1000$, respectively. After repeat incubation and washing $100 \mu \mathrm{l}$ of tetramethyl-benzidine substrate was added. The reaction was stopped with $50 \mu \mathrm{l}$ of $1 \mathrm{M}$ sulphuric acid after incubation in the dark at room temperature for 30 minutes. Absorbance was read at $450 \mathrm{~nm}$, and a linear area under the curve result was calculated, using the absorbance of serial dilutions in a simple Simpson test.

Student's $t$ test and the $\chi^{2}$ test were used to test statistical significance. A probability of less than $5 \%$ was considered to be significant.

\section{Results}

\section{ENDOSCOPY AND BIOPSY}

A total of 222 patients were studied. Twenty five had endoscopically diagnosed duodenal ulcer and 21 gastric ulcers. One hundred and thirty one of the antral biopsy specimens were within normal limits histologically (grade 0 ), and of the remainder, 28 had grade 1 gastritis, 25, grade 2, 13, grade 3, and 21, grade 4 . Three specimens showed peptic ulceration, and one was unavailable. Seventy seven $(35 \%)$ biopsy specimens proved to be positive on culture, and 145 were negative. Table 1 shows a comparison of those that were negative with those that were positive. There was a very strong association of a positive culture with duodenal ulcer and gastritis, but only a weak association with gastric ulcer. There were 109 patients with no endoscopic ulcers or histological abnormalities and of these, only eight $(7 \%)$ were positive on

Table 1 Comparison of $C$ pyloridis positive and negative patients (figures in parentheses are numbers \%)

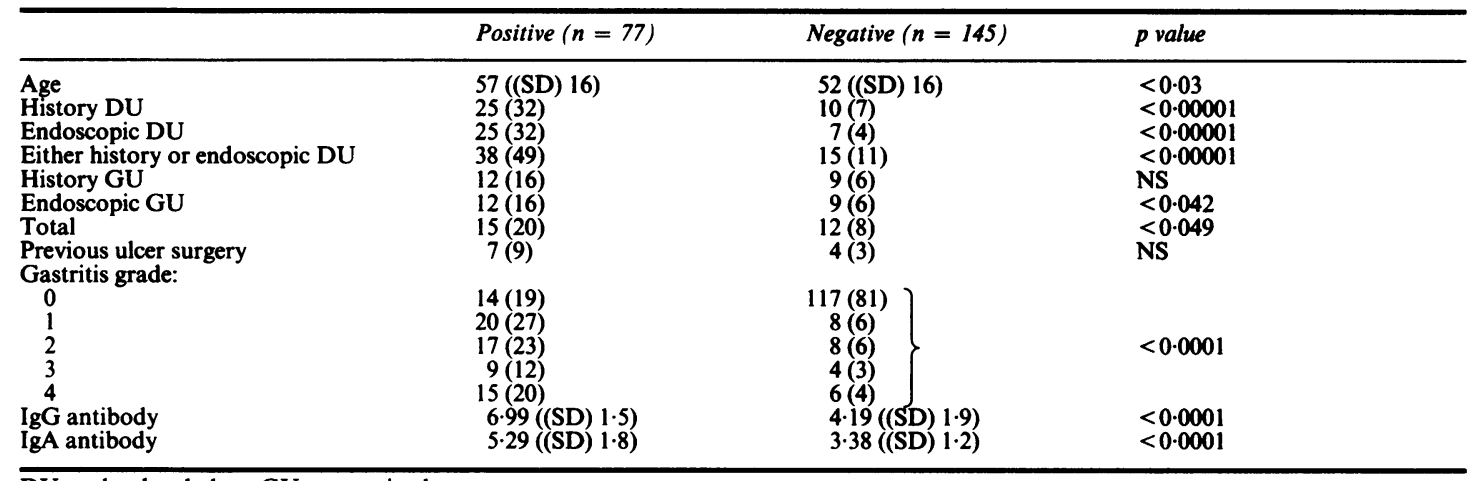

$\mathrm{DU}=$ duodenal ulcer; $\mathbf{G U}=$ gastric ulcer. 
Table 2 Mean (SD) serum IgA and IgG antibody values of patients according to diagnostic group

\begin{tabular}{llll}
\hline & $\begin{array}{l}\text { No of } \\
\text { patients }\end{array}$ & $\begin{array}{l}\text { IgG } \\
\text { (units) }\end{array}$ & $\begin{array}{l}\text { IgA } \\
\text { (units) }\end{array}$ \\
\hline Gastritis & 62 & $6.9(1.6)$ & $5.7(1.3)$ \\
Gastric ulcer & 10 & $7.09(2 \cdot 1)$ & $5.05(1.4)$ \\
Duodenal ulcer & 23 & $6.2(1.7)$ & $4.97(1.45)$ \\
No disease & 55 & $4.07(1.9)^{*}$ & $3.39(1)^{*}$ \\
\hline
\end{tabular}

${ }^{*} \mathrm{p}<\cdot 001$ compared with all other groups.

culture. No evidence of a carry over effect of the organism (by endoscope from one patient to the next) could be detected.

\section{ANTIBODY STUDIES}

Both IgG and IgA antibody concentrations were significantly higher in patients with $C$ pyloridis. Table 2 shows the results of the IgG and IgA assays in the patient subgroups. The patients with neither endoscopic ulcers nor histological abnormalities had significantly lower values than those of the disease groups $(p<0.001)$. Table 3 shows the results in patients with gastritis subgrouped according to the histological 70 . Those who were histologically normal had significant lower amounts of IgA and IgG antibody than the patients of either of the other grades ( $p$ $<0.001)$.

To ascertain whether these immunoglobulin assays could detect gastritis or peptic ulceration we arbitrarily divided the results into low $(<2.9)$, medium, and high $(>5.9)$ ranges. Table 4 shows the correlations with the presence or absence of $C$ pyloridis, or disease. 35 of the 51 patients $(68 \%)$ with high IgG values and 15 of $17(88 \%)$ with high IgA values were $C$ pyloridis positive. None of the 25 patients with low IgG values and only five of the $71(7 \%)$ with low IgA values were found to have positive culture. Endoscopic or histological abnormality was found in four of 45 patients $(9 \%)$ with low IgG.values, but in $\mathbf{4 0}$ of $51(78 \%)$ with high IgG values. Respective results for IgA were 13 of $71(18 \%)$ and 17 of $17(100 \%)$.

Table 5 shows the antibody results of the control group, indicating that IgG and IgA titres increase with age. In 76 patients with no ulcers and normal histology (age range 21-81 years), however, there was no correlation between age and antibody titre ( $r=$ $0 \cdot 14)$.

\section{Discussion}

Our rate of isolation for $C$ pyloridis is lower than that of some studies, but so too was the incidence of confirmed gastrointestinal disease. We have shown that an isolation of $C$ pyloridis is strongly associated with duodenal ulceration and the presence of histological gastritis. Ulcers and gastritis often coexist, and $66 \%$ of patients with duodenal ulcers and $75 \%$ of those with gastric ulcers had antral gastritis. If the correlation between $C$ pyloridis isolation and duodenal ulceration merely reflected coexistent gastritis then a stronger association would also have been expected between gastric ulceration and $C$ pyloridis isolation. Thus $C$ pyloridis may yet be another factor to be considered in the differing aetiology of gastric and duodenal ulceration. Both IgG and $\operatorname{IgA}$, however, were significantly raised in gastric ulcer patients compared with that in controls.

Warren and Marshall showed a strong association between $C$ pyloridis isolation and gastric, as well as duodenal ulcers. $^{8}$ Jones et $a l^{13}$ found no relation between serology and peptic ulcers. ${ }^{813}$ Kaldor's group ${ }^{13}$ used serology to distinguish between patients with peptic ulcers and laboratory staff, but did not differentiate between gastric and duodenal ulcers. In our hands measurements of IgG and IgA were complementary, although IgA was slightly more specific, presumably because of the importance of $\operatorname{IgA}$ as the gut mucosal antibody. Measuring IgA in gastric juice might be more specific.

Ulcers recur and remit, gastritis is patchy, and a single biopsy may not represent the stomach as a whole. It would, therefore, have been surprising if complete correlation between the isolation of $C$ pyloridis antibody and disease had been shown. Furthermore, antigenic variation within $C$ pyloridis may exist, ${ }^{17}$ and so a sonicate of pooled organisms may have been a better antigen for the ELISA.

Kaldor $^{13}$ found less $C$ pyloridis antibody in children than in adults. We found that antibody increased with age in our control populations, but not

Table 3 Mean (SD) serum IgG and IgA antibody values (units) in patients divided according to histological grades of gastritis

\begin{tabular}{|c|c|c|c|c|c|}
\hline & \multicolumn{5}{|c|}{ Grade of gastritis } \\
\hline & 0 & $I$ & 2 & 3 & 4 \\
\hline $\begin{array}{l}\text { Age } \\
\text { IgG } \\
\text { IgA }\end{array}$ & $\begin{array}{l}50(16) \\
4 \cdot 2(1 \cdot 9)^{*} \\
3.4(1 \cdot 2)\end{array}$ & $\begin{array}{l}57(16) \\
7 \cdot 2(1 \cdot 8) \\
5 \cdot 3(1 \cdot 1)\end{array}$ & $\begin{array}{l}57(14) \\
6 \cdot 5(1.9) \\
5 \cdot 0(1 \cdot 3)\end{array}$ & $\begin{array}{l}57(16) \\
6.6(2) \\
4.6(1 \cdot 6)\end{array}$ & $\begin{array}{c}60(11) \\
7.2(0.96) \\
5.5(1.3)\end{array}$ \\
\hline
\end{tabular}

* Significantly different $(p<0.001)$ relative to values of each grade $1-4$. 
Table 4 Correlation of serum of $\operatorname{Ig} G$ and $\operatorname{Ig} A$ results divided into low, medium, or high range with presence of $C$ pyloridis and presence (or absence) of ulcers or gastritis (disease)

\begin{tabular}{lclll}
\hline & $\begin{array}{l}\text { Isolate } \\
\text { positive }\end{array}$ & $\begin{array}{l}\text { Isolate } \\
\text { negative }\end{array}$ & Disease & $\begin{array}{l}\text { No } \\
\text { disease }\end{array}$ \\
\hline IgG: & & & & \\
Low (45) & 0 & 45 & 4 & 41 \\
Medium (44) & 14 & 30 & 26 & 18 \\
High (51) & 35 & 16 & 11 & 40 \\
IgA: & & & 13 & 58 \\
Low (71) & 5 & 66 & 32 & 20 \\
Medium (82) & 30 & 22 & 17 & 0 \\
High (17) & 15 & 2 & & \\
\hline
\end{tabular}

in a group of adult patients known to have normal histology and no ulceration. The incidence of gastritis is known to increase with age, even in healthy populations, ${ }^{18}$ and this observation explains this apparent paradox.

Koch's postulates are beginning to be fulfilled for $C$ pyloridis and gastritis following Marshall's ingestion of a strain that resulted in confirmed gastritis. ${ }^{19-21}$ An interesting observation relating to gastritis was the rarity of $C$ pyloridis in gastritis of immune origin, such as pernicious anaemia. ${ }^{22}$ This suggests that it is unlikely to be a secondary invader and provides indirect evidence of its pathogenicity in other forms of gastritis. Meyrick-Thomas suggested that the absence of $C$ pyloridis in gastritis of immune origin was due to the increased prevalence of intestinal metaplasia in this group. ${ }^{23}$ His group ${ }^{24}$ and that of Phillips ${ }^{25}$ noted that $C$ pyloridis was absent from gastric mucosa showing intestinal metaplasia. In our study, however, patients with grade 4 gastritis (by definition showing metaplasia) had high mean titres of IgG and IgA (Table 3), and $C$ pyloridis was isolated from 15 of 21 patients.

Ulcer healing was associated with a considerable decrease in the number of mucosal related bacteria in one $^{10}$ but not all studies. ${ }^{2021}$ Marshall's group noted that decreasing antibody titres coincided with ulcer healing. ${ }^{12}$ The mean serum antibody titre of five of our patients with healed duodenal ulcers was no less than that of 10 patients with active ulcers. Our patients, however, unlike those of Marshall's

Table 5 IgG and IgA results (mean (SD)) for control sera divided according to age group

\begin{tabular}{llll}
\hline $\begin{array}{l}\text { Age } \\
\text { (years) }\end{array}$ & No & IgG (units) & IgA (units) \\
\hline$<14$ & 56 & $2 \cdot 3(1 \cdot 22)$ & $2 \cdot 4(0 \cdot 76)$ \\
$14-44$ & 25 & $4 \cdot 2(1 \cdot 68)$ & $2 \cdot 5(1 \cdot 07)$ \\
$45-64$ & 23 & $5 \cdot 8(1 \cdot 9)$ & $3 \cdot 2(1 \cdot 07)$ \\
$>64$ & 54 & $6 \cdot 1(3 \cdot 8)$ & $3 \cdot 8(1.05)$ \\
\hline
\end{tabular}

group, ${ }^{11}$ had not received any antibacterial treatment. As gastritis persists after ulcer healing with conventional agents this could explain the lack of any reduction in antibody titres seen in our patients, although it is difficult to draw valid conclusions from so few patients. Longitudinal studies on individual patients are required.

We conclude that the association of $C$ pyloridis with gastritis and peptic ulcer is confirmed in this study. Further study is required-for example, whether the different subgroups of organisms are associated with specific disease states. Similarly intervention trials are required to evaluate the effect of antibacterial treatment. Refinements of the immunological tests offer the possibility of a useful noninvasive test for gastritis and peptic ulceration that could be particularly appropriate for screening large populations.

\section{References}

${ }^{1}$ Warren JR. Unidentified curved bacilli on gastric epithelium in active chronic gastritis. Lancet 1983;i:1273.

${ }^{2}$ Marshall B. Unidentified curved bacilli in active chronic gastritis. Lancet 1983;i:1273-5.

${ }^{3}$ Marshall BJ, Royce H, Annear DI, et al. Original isolation of Campylobacter pyloridis from human gastric mucosa. Microbios Lett 1984;25:83-8.

${ }^{4}$ Rollason TP, Stone J, Rhodes JM. Spiral organism in endoscopic biopsies of the human stomach. J Clin Pathol 1984;37:23-6.

${ }^{5}$ McNulty CAM, Watson DM. Spiral bacteria of the gastric antrum. Lancet 1984;i:1068-9.

${ }^{6}$ Eldridge J, Lessels AM, Jones DM. Antibody to spiral organisms in the gastric mucosa. Lancet 1984;i:1237.

' Langenberg M-L, Tytgat GNJ, Schipper MEI, Rietra PJGM, Zanen HC. Campylobacter-like organisms in the stomach of patients and healthy individuals. Lancet 1984;:1348.

${ }^{8}$ Burnett RA, Forrest JAH, Girdwood RWA, Fricker CR. Campylobacter-like organisms in the stomach of patients with gastritis and peptic ulceration. Lancet 1984;i:1389.

${ }^{9}$ Marshall BJ, Warren JR. Unidentified curved bacilli in the stomach of patients with gastritis and peptic ulceration. Lancet 1984;i:1311-15.

${ }^{10}$ Shousha S, Bull TB, Parkins RA. Gastric spiral bacteria. Lancet 1984;ii:101.

${ }^{11}$ Steer H. Mucosa-related bacteria in the stomach. Lancet 1984;ii:528.

12 Marshall BJ, McGechie DB, Francis GJ, Utley PJ. Pyloric Campylobacter serology. Lancet 1984;ii:281.

${ }^{13}$ Kaldor J, Tee W, McCarthy P, Watson J, Dwyer B. Immune response to Campylobacter pyloridis in patients with peptic ulceration. Lancet 1985; ;:921.

14 Jones DM, Lessels AM, Eldridge J. Campylobacter-like organisms on the gastric mucosa: culture, histological and serological studies. J Clin Pathol 1984;37:1002-6.

${ }^{15}$ Whitehead R. Mucosal biopsy of the gastrointestinal tract. WB Saunders Co, Philadelphia: 1973:17-32.

${ }^{16}$ Rathbone BJ, Wyatt JI, Worsley BW, et al. Immune response to Campylobacter pyloridis. Lancet 1985; 1217.

${ }^{17}$ Ireland A, Bamforth J, Pearson AD, et al. Polyacrylamide gel electrophoresis of spiral bacteria from the gastric antrum. Lancet 1984;i:1349-50. 
${ }^{18}$ Siurala M, Isokoscki M, Varis K, Kekki M. Prevalence of gastritis in a normal population. Scand J Gastroenterol 1968;6:211-23.

${ }^{19}$ Anonymous. Pyloric Campylobacter finds a volunteer. [Editorial]. Lancet 1985; i:1021-2.

${ }^{20}$ Marshall BJ, Armstrong JA, McGechie DB, Glancy RJ. Attempt to fulfil Koch's postulates for pyloric Campylobacter. Med J Aust 1985;142:436-9.

${ }^{21}$ Marshall BJ, McGechie DB, Rogers PA, Glancy RJ. Pyloric Campylobacter infection and gastroduodenal disease. Med $J$ Aust 1985;142:439-44.

${ }^{22}$ O'Connor HJ, Axon ATR, Dixon MF. Campylobacter-like organisms unusual in type A (pernicious anaemia) gastritis. Lancet 1984;ii:1091.
${ }^{23}$ Meyrick-Thomas J. Campylobacter-like organisms in gastritis. Lancet 1984;ii:1217.

${ }^{24}$ Poynter D, Gooding C, Meyrick-Thomas J, et al. Gastric spiral bacteria. Lancet 1984;ii:100.

${ }^{25}$ Phillips AD, Hine KR, Holmes GKT, Woodings DF. Gastric spiral bacteria. Lancet 1984;ii:100-1.

Requests for reprints to: Dr G Holdstock, Professorial Medical Unit, Room LD 72, Level D, Southampton General Hospital, Tremona Road, Southampton SO9 4XY, England. 